\title{
THE INFLUENCE OF SECURITY, TRUST, SERVICE QUALITY AND RISK PERCEPTION IN B2C E- COMMERCE AGAINTS PEOPLE'S ONLINE PURCHASING DECISIONS (SURVEY ON CUSTOMERS OF TOKOPEDIA)
}

\author{
Ford Lumban Gaol ${ }^{1}$ and Erik Chen ${ }^{2}$ \\ ${ }^{1}$ Computer Science Department, BINUS Graduate Program - Doctor of Computer \\ Science, Bina Nusantara University, Jakarta, Indonesia \\ ${ }^{2}$ Computer Science Department, BINUS Graduate Program-Master of \\ Information System, Bina Nusantara University, Jakarta, Indonesia \\ ${ }^{1}$ fgaol@binus.edu, 2erik002@binus.ac.id
}

\begin{abstract}
This research was aimed to find out the influence of security, trust, service quality, and risk perception on customer's online purchasing decisions. This research used quantitative approach by applying survey method. Population used in this research is TOKOPEDIA's customer in Jakarta. From the sample of 400 respondents, the result of the research shows that: (1) Security have a significance influence on online purchasing decision, proved by the result of $t$ value 3.901 with significance value of 0.000 , smaller than 0.05 and the value of regression coefficient is 0.217 ; (2) Trust has a significance influence on online purchasing decision, proved by the result of $t$ value 2.210 with significance value of 0.028 , smaller than 0.05 and the value of regression coefficient is 0.112 ; (3) Service quality has a significance influence on online purchasing decision, proved by the result of $t$ value 11,018 with significance value of 0.000 , smaller than 0.05 and the value of regression coefficient is 0.387 ; (4) Risk perception has no significance influence on online purchasing decisions, proved by the result of $t$ value 1,405 with significance value of 0.686 , greater than 0.05 and the value of regression coefficient is 0.015 .
\end{abstract}

Keywords - Security, Trust, Service Quality, Perception of Risk, Online Purchasing Decisions

\section{INTRODUCTION}

In the globalization era like today, e-commerce is rapidly evolving. The development of information technology today is intensively supported by the technology infrastructure that has been built by both government and private parties. The rapid development of internet also gives a significant influence in various aspects of life; one of them is in the business world. Consumers in a number of developing countries in Asia Pacific are consumers who prioritize the mobile use (mobile-first) and have exceeded the evolution of traditional payments. Governments in the region have made significant efforts to encourage the development of electronic and mobile commerce landscapes (e-commerce and m-commerce) and also the development of supporting infrastructure. More than half of respondents in Indonesia (58.5 percent) have made purchases using their smartphones, with flexibility and convenience (49.9\%), and the ease of online purchasing with the

Received: December 23, 2018

Reviewed: February 25, 2019

Accepted: February 28, 2019

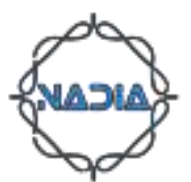


presence of diverse applications (43.5\%) is the main reason for doing mobile shopping [17]. One type of e-commerce that is currently growing rapidly in Indonesia is ecommerce type of marketplace. Marketplace is an online place where sellers can create accounts and peddle their wares. One of the advantages of selling in the marketplace is the seller does not need to create a site or personal online store. Regardless of the rapid growing of the e-commerce, many people still consider to make online purchase on the internet. There are some issues that make people think twice before make online purchasing. The most frequent cases that happened related to online purchasing are: theft of credit card data, fraud, fake product description, irresponsible seller, product sent differ with image provided by the seller, and many more. Therefore, most of the people are afraid when they want to make online purchasing. TOKOPEDIA has been established since August 17, 2009. After standing for 9 years, now TOKOPEDIA has grown into the largest ecommerce company in Indonesia. For the category of e-commerce, TOKOPEDIA is the most widely accessed site of Indonesian internet users [26].

There are a lot of factors that influence people when making decision to do online purchasing such as trust, security, risk, service quality, and so on. In this research, writer wants to test the influence of some factors that believe to have influence on people's decision to making online purchasing. Based on the importance of security, trust, service quality and perception of risk that influencing online purchasing decisions, writer is interested to test the influence that occurs between the variables.

\section{RESEARCH METHOD}

This research uses causal associative research method and using quantitative approach. Quantitative approach is the approach in research using data in the form of numbers. Causal associative research is a research looking for relationship or causal influence that is relationship or influence of independent variable $(\mathrm{X})$ to dependent variable $(\mathrm{Y})$ [30]. This research is structured as an inductive research that searches and collects existing data in the field to know factors, form elements, and a characteristic of phenomenon in society. This research will analyze the influence of security, trust, service quality and risk perception in B2C e-commerce on customer's online purchasing decision. In this research there is one dependent variable that is online purchasing decision which is allegedly influenced by four independent variables that is security, trust, service quality and risk perception using e-commerce.

In this research there is one dependent variable that is online purchasing decision which is allegedly influenced by four independent variables that is security, trust, service quality and risk perception using e-commerce. Based on the framework, the scheme / model in this research are as follows: 


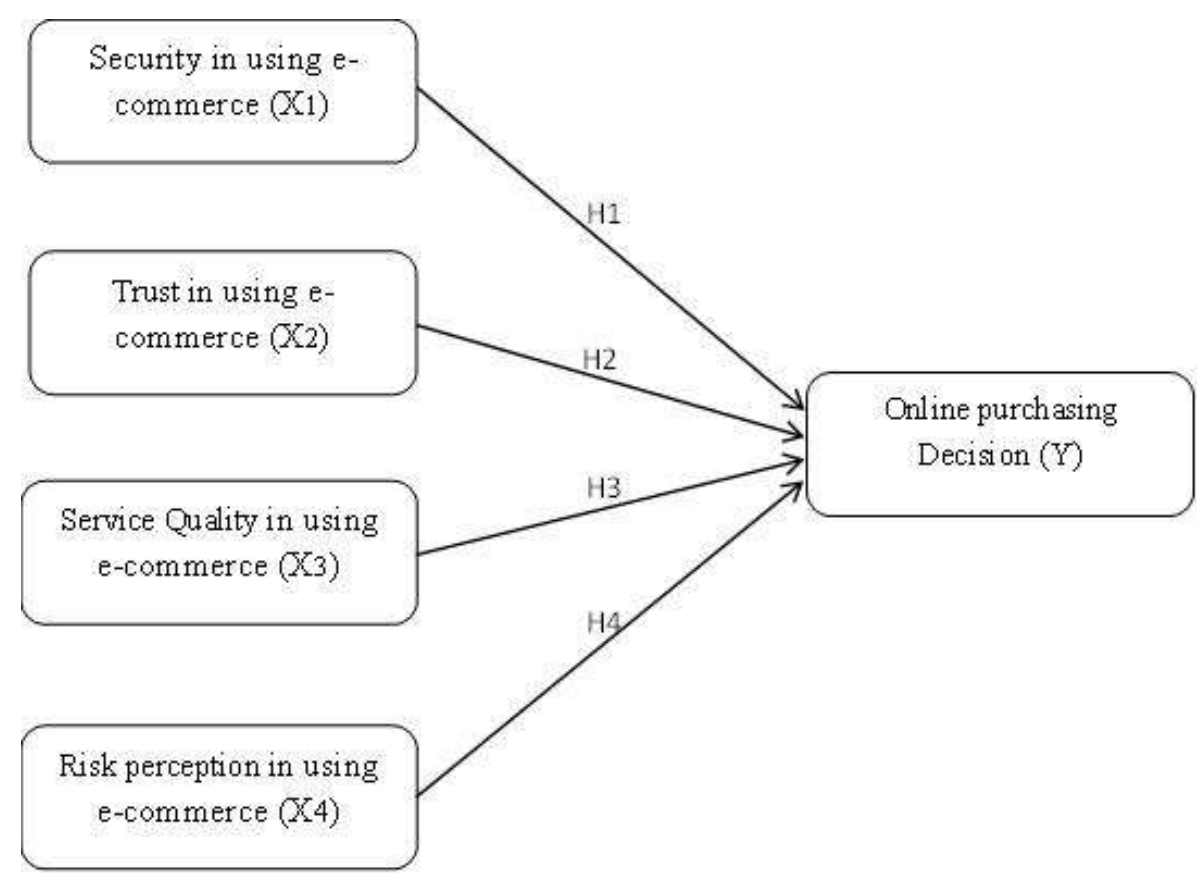

Fig. 1 Research Model

\section{THEORITICAL FOUNDATION}

\subsection{E-COMMERCE}

E-commerce is a form of doing business that is performed online or over the internet. In simple terms, when you buy or sell something online or via an electronic medium, it is referred as electronic commerce, popularly known as E-commerce. Because of its vast reach and popularity, it has completely changed the way business is done and has been adopted by everyone from small businesses to the big giants. In recent years, research on electronic commerce (e-commerce) has been increasingly varied. It makes the definition of e-commerce very diverse. E-commerce is part of a transaction-focused technology that includes online buying and selling, digital product creation, virtual marketplace and distribution channels with new media [29]. E-commerce refers to the purchase or ordering of goods via the internet for personal or household consumption, regardless of whether payment is made when goods are received or directly via credit card, e-payment, ebanking and so on [15]. E-commerce also defined as a process of buying, selling, sending or exchanging products, services and information through computer networks, including the internet [24]. In Indonesia today, Electronic commerce is increasingly used to transact as seen from the growth of e-commerce in Indonesia such as TOKOPEDIA, LAZADA, BliBli.com, JD.id, Kaskus, Fave (originally disdus.com), jakartanotebook.com / jakmall .com and many more.

There are five different types of electronic commerce: 1. Business to Customer ecommerce - an online business that sells to individual consumers; 2. Business to business e-commerce - an online business that focuses on selling to other businesses; 3 . Customer to Customer e-commerce - consumers are people who sell products or services to fellow consumers; 4. Peer to peer e-commerce - online technology that allows Internet users to share files and computer resources directly without having to go through a central web server; 5. Mobile commerce - sale and purchase transactions on the web through wireless digital devices to connect mobile phones and personal computers to the web such as stock trading, banking, travel reservations and others [14]. 


\subsection{SECURITY, TRUST, SERVICE QUALITY, AND RISK PERCEPTION}

Security issues are one important aspect of an information system. The security of online transactions is how to prevent fraud or at least detect fraud in an information-based system, where the information itself has no physical meaning. The security of online transactions continues to dominate the discussion of e-commerce. Security indicators include: 1 . Security guarantee; and 2. Data privacy [25].

The main thing a buyer will consider when make online purchasing is whether they believe in a site that provides online shop service facilities and believes in online vendors within the site. Trust established between parties who have not known each other well in the interaction and transaction process [16]. Indicators of trust are: 1. Honesty in managing online trading sites; 2 . Competence, the site can be competitive and reliable; 3. the information provided can be trusted [16].

Many experts in the field of quality tried to define quality based on their point of view. Some of the most popular ones are developed by three international quality experts, namely W. Edwards Deming, Philip B. Crosby and Joseph M. Juran, Deming defines quality is anything that becomes the needs and desires of consumers. Crosby defines quality as nil defects, perfection and conformity to requirements, while Juran defines quality as conformity to the specification, when viewed from the point of the manufacturer view [32]. The five dimensions of service quality characteristics are: 1 . Reliability; 2. Responsiveness; 3. Assurance; 4. Empathy; 5. Tangibles

In internet transaction, risks are perceived to be higher than physical trading due to the limited physical contact of consumers to the product, means that the consumers can not control the product performance before making a purchase. In online transactions, there are at least three possible risks: product risk, transaction risk and psychological risk [31]: 1. Product risk; 2. Transaction risk; 3. Psychological risk. There are 3 factors that called triple stands that influence perceptions and attitudes of risk: 1. Conscious; 2. Subconscious; and 3. Affective; these three factors play an important role in influencing perceptions, where perceptions encourage attitudes toward risks that determine the quality of decision-making created under uncertain situations [10].

\section{RESEARCH RESULT AND DISCUSSION}

This research is aims to the influence of security, trust, service quality and risk perception in $\mathrm{B} 2 \mathrm{C}$ e-commerce on online purchasing decisions for both TOKOPEDIA users who have made online purchases at TOKOPEDIA once or more than once. The analysis used in this study includes descriptive statistical analysis, classical assumption test, regression analysis, and hypothesis testing. This analysis is used in accordance with the formulation of the model and the existing problems.

Characteristics of respondents based on the gender are classified into two groups. Grouping is done to make it easier to describe the data. From 400 respondents there are $206(52 \%)$ respondents who are females, while 194 (48\%) are male.

Characteristics of respondents based on their age are classified into five groups. Grouping is done to make it easier to describe data. Of the 400 respondents, the most are for group of age 18-25 years old with 208 respondents (52\%), < 18 years old group with 58 respondents (15\%), 26-35 years old group with 101 respondents $(25 \%)$, and the lowest number is for group of age $>35$ years old as many as 33 people (8\%).

Characteristics of respondents based on education level are classified into five groups. Grouping is done to make it easier to describe data. Of the 400 respondents, the most were Strata 1 groups with 252 respondents (63\%), Diploma group with 52 respondents (13\%), < SMA group with 54 respondents (13\%), and the group with the lowest number is the Strata 2 group as many as 42 people (11\%).

Characteristics of respondents based on the frequency of internet use are classified into five groups to make it easier to describe the data. Of the 400 respondents, the most time 
to use the internet per week is the group of $>20$ hours with 275 respondents (69\%), 6-10 hours group with 35 respondents (9\%), 11-15 hours group with 20 respondents (5\%), 1620 hours group with 58 respondents (14\%), and the group with the lowest number is the < 6 hours usage period with 12 respondents (3\%).

Characteristics of respondents based on the frequency of purchase transactions are classified into two groups in order to make it easier to describe the data. Out of 400 respondents, 321 respondents $(80 \%)$ made more than once transactions and 79 respondents $(20 \%)$ made once.

The data of the research results are categorized into three groups: high, medium, low. The following data categorization results: I. Security: number of respondents who gave an assessment of the variables of security in the high category are 231 respondents (57.75\%), medium category 165 respondents $(41.25 \%)$, and low category 4 people $(1.0 \%)$; II. Trust: number of respondents who gave an assessment of the variables of trust in the high category are 242 respondents $(60.50 \%)$, medium category 152 respondents $(38 \%)$, and low category 6 people (1.50\%); III. Service Quality: number of respondents who gave an assessment of the variables of service quality in the high category are 157 respondents (39.25\%), medium category 239 respondents $(59.75 \%)$, and low category 4 people (1.50\%); IV. Risk Perception: number of that respondents who gave an assessment of the variables of service quality in the high category are 47 respondents $(11.75 \%)$, medium category 256 respondents (64\%), and low category 97 people (24.25\%); V. Purchase Decision: number of respondents who gave an assessment of the variables of service quality in the high category are 271 respondents $(67.75 \%)$, medium category 126 respondents $(31.50 \%)$, and low category 3 people $(0.75 \%)$.

The results of hypothesis testing in this study are as follows:

Table I. Result of Multiple Regression Analysis (Source: Survey Result, 2018)

\begin{tabular}{|l|c|c|c|c|c|}
\hline Independent Variables & $\begin{array}{c}\text { Reg. } \\
\text { Coef. }(\boldsymbol{\beta})\end{array}$ & $\begin{array}{c}\text { t- } \\
\text { count }\end{array}$ & t-table & Sig. & Summary \\
\hline Security (X1) & 0,217 & 3,901 & 1,970 & 0,000 & Significance \\
\hline Trust (X2) & 0,112 & 2,210 & 1,970 & 0,028 & Significance \\
\hline Service Quality (X3) & 0,387 & 11,018 & 1,970 & 0,000 & Significance \\
\hline Risk Perception (X4) & 0,015 & 0,405 & 1,970 & 0,686 & $\begin{array}{c}\text { Not } \\
\text { Significance }\end{array}$ \\
\hline Constants $=10,186$ & & & \\
\hline Adjusted $\mathrm{R}^{2}=0,514$ & Sig. $=0,000$
\end{tabular}

The multiple regression equation based on the results of the regression analysis can be known as follows:

$$
\mathrm{Y}=10,186+0,217 \mathrm{X} 1+0,112 \mathrm{X} 2+0,387 \mathrm{X} 3+0,015 \mathrm{X} 4+\mathrm{e}
$$

The explanation for the $t$ test on each independent variable is as follows: 


\section{Security}

Security has a significance level of 0,000 . From the results of the $t$ test on the security variable states that the significance of the test is smaller than 0,05 and the regression coefficient has a positive value of 0,217 . While the value of t-count obtained is 3,901 which is greater than the value of t-table, which is 1.970 . Based on these results, the hypothesis "security has a significance influence on online purchasing decisions" is acceptable.

\section{2. $\quad$ Trust}

Trust has a significance level of 0,028. From the results of the t test on the trust variable states that the significance of the test is smaller than 0,05 and the regression coefficient has a positive value of 0,112 . While the value of t-count obtained is 2,210 greater than the value of t-table which is 1.970. Based on these results, the hypothesis "Trust has a significance influence on online purchasing decisions" is acceptable.

\section{Service Quality}

Service quality has a significance level of 0.000. From the results of the $t$ test on the service quality variable states that the significance of the $t$ test is smaller than 0.05 and the regression coefficient has a positive value of 0.387 . While the value of $t$-count obtained is 11,018 greater than the value of t-table, which is 1.970 . Based on the data, the hypothesis "service quality has a significance influence on online purchasing decisions" is acceptable.

\section{CONCLUTIONS}

Based on the results of the research and discussion in chapter IV, some conclusions can be taken as follows:

1. Security has a significance influence on online purchasing decisions. This is evidenced by the regression coefficient of 0.217 and the significance value of $t$-count of 0.000 ( $\mathrm{sig}<0.05$ ). The value of $\mathrm{t}$-count obtained is greater than $\mathrm{t}$ table which is $3.901>$ $1.970 ; 2$. Trust has a significance influence on online purchasing decisions. This is evidenced by the regression coefficient of 0.112 and the significance value of t-count of 0.028 ( $\mathrm{sig}<0.05$ ). The value of $\mathrm{t}$-count obtained is greater than $\mathrm{t}$ table, which is $2.210>$ $1.970 ; 3$. Service quality has a significance influence on online purchasing decisions. This is evidenced by the regression coefficient of 0.387 and the significance value of t-count is 0.000 ( $\mathrm{sig}<0.05$ ). The value of $\mathrm{t}$-count obtained is greater than $\mathrm{t}$ table, namely 11,018 > 1,$970 ; 4$. Risk perception has no significance influence on online purchasing decisions. This is evidenced by the regression coefficient of 0.015 and the significance value of $t-$ count is 0.686 ( $\mathrm{sig}>0.05$ ). The value of $t$-count obtained is smaller than $t$ table, which is $1,405<1.970 ; 5$. The amount of Adjusted $\mathrm{R}^{2}$ in this study is 0.514 . This shows that the magnitude of the influence of the variables of security, trust, service quality, and risk perception is $51.4 \%$, while the remaining $48.6 \%$ is influenced by other factors which not included in this research.

\section{REFERENCES}

[1] Akin, Zafer. (2015). Risk Behavior, Risk Perception and Online Shopping: An Experimental Approach.

[2] Ambrose, P., \& Johnson, G. (1998). A Trust Based Model of Buying Behaviour in Electronic Retailing. AMCIS Proceedings Paper 91.

[3] Asosiasi Penyelenggara Jasa Internet Indonesia. (2017, 09). Infografis Penetrasi \& Perilaku Pengguna Internete Indonesia Survey 2017. Retrieved from https://www.apjii.or.id/survei2017

[4] Ba, S., \& Pavlou, P. A. (2002). Evidence of the effect of trust building technology in electronic markets: price premiums and buyer behavior. MIS Quarterly vol 26 no 3, 243-268.

[5] Ba, S., Whinston, A. B., \& Zhang, H. (2003). Building trust in online auction markets through an economic incentive mechanism. Decision Support Systems, vol. 35, no. 3, 273-286. 
[6] Chaffey, D. (2009). E-business and e-commerce management - Strategy, implementation, and practice. Foruth Edition. Prentice Hall.

[7] Chen, J., Zhang, C., \& Xu, Y. (2009). The Role of Mutual Trust in Building Members' Loyalty to a C2C Platform Provider. International Journal of Electronic Commerce, Vol. 14 No. 1, 147-171.

[8] David P. Mackinnon (2011) Integrating Mediators and Moderators in Research Design. Res Soc Work Pract, 6. accessed November 20, 2017, retrieved from https://www.ncbi.nlm.nih.gov/pmc/articles/PMC3366634/pdf/nihms375758.pdf

[9] Gefen, D., Karahanna, E., \& Straub, D. W. (2003). Trust and TAM in Online Shopping: An Integrated Model. MIS Quarterly 27, 51-90.

[10] Hillson, David, and Ruth Murray-Webster. "Understanding and managing risk attitude." Proceedings of 7th Annual Risk Conference, held in London, UK. Vol. 26. 2004.

[11] Hennig-Thurau, T., Gwinner, K. P., Walsh, G., \& Gremler, D. D. (2004). Electronic word-of-mouth via consumer-opinion platforms: What motivates consumers to articulate themselves on the internet? Journal of Interactive Marketing, 38-52.

[12] Kim, D. J., Ferrin, D. L., \& Rao, H. R. (2008). A Trust-Based Consumer Decision Model in Electronic Commerce: The Rolf of Trust, Risk, and Their Antecedents.

[13] Kim, H.-W., Xu, Y., \& Gupta, S. (2012). Which is more important in Internet shopping, perceived price or trust? Electronic Commerce Research and Applications 11, 241-252.

[14] Laudon, K. C., \& Traver, C. G. (2016). E-commerce 2016 business. technology. society. Twelfth Edition. Pearson Education Limited.

[15] Lignell, A. (2014). Older Consumers' Adoption of Online Shopping.

[16] McKnight, D. Harrison, Vivek Choudhury, and Charles Kacmar. 2002. Developing and Validating Trust Measure for E-Commerce: An Integrative Typology. Information System Research. Vol. 13, p334-359.

[17] Master Card Mobile Shopping Survey (2017), accessed July 30, 2018, Retrieved from https://newsroom.mastercard.com/asia-pacific/press-releases/emerging-markets-lead-mobile-shoppingcharge-in-asia-pacific-mastercard-survey-reveals/

[18] Maulina Hardiyanti, 2012, "Kepercayaan Pada Penjual dan Persepsi Akan Risiko Pada Keputusan Pembelian Melalui Internet (Online)", Skripsi (not published), Fakultas Ilmu Sosial dan Humaniora, Universitas Islam Negeri Sunan Kalijaga, Yogyakarta.

[19] O'Brien, J. A., \& Marakas, G. M. (2011). Management Information Systems.McGraw-Hill Irwin

[20] Pavlou, P. A., dan Gefen, D., 2002. Building Effective Online Marketplaces with Institution-based Trust, Proceedings of Twenty-Third International Conference on Information Systems, pp. 667-675.

[21] Pavlou, P. A. (2003). Consumer Acceptance of Electronic Commerce: Integrating Trust and Risk with the Technology Acceptance Model. International Journal of Electronic Commerce Vol. 7, No. 3, 69103.

[22] Pavlou, P. A., \& Dimoka, A. (2005). The Nature and Role of Feedback Text Comments in Online Marketplaces: Implications for Trust Building, Price Premiums, and Seller Differentiation. Information Systems Research Volume 17, Issue 4, 392 - 414.

[23] Pavlou, P., \& Gefen, D. (2004). Building Effective Online Marketplaces with Institution-Based Trust. Information Systems Research, vol. 15, 37-59.

[24] Rainer, R. K., \& Cegielski, C. G. (2011). Introduction to Information Systems: Enabling and Transforming Business Third Edition. Jonh Wiley \& Sons Inc.

[25] Raman, Arasu., dan Viswanathan, A. 2011. Web Services and e-Shopping Decisions: A Study on Malaysian e-Consumer. IJCA Special Issue on:Wireless Information Networks \& Business Information System, p54-60.

[26] Similarweb.com. (2017, 01). Accessed July 30. 2018 Top Shopping Websites in Indonesia. Retrieved from https://www.similarweb.com/top-websites/indonesia/category/shopping

[27] Schiffman, L \& Kanuk L.L (2008), Perilaku Konsumen Edisi 7, Jakarta: Indeks.

[28] Solomon, M. R. (2011). Consumer Behavior, 9th Edition. Pearson Education Limited

[29] Strauss, J., \& Frost, R. (2014). E-Marketing.

[30] Sugiyono. (2009). Metode Penelitian Bisnis (Pendekatan Kuantitatif, Kualitatif, dan R\&D). Bandung: Alfabeta.

[31] Suresh, A.M., dan Shashikala R. 2011. Identifying Factors of Consumer Perceived Risk towards Online Shopping in India. IPEDR. 12. p.336-341.

[32] Z. Yamit, Manajemen Kualitas Produk dan Jasa, Jakarta: Gramedia Pustaka Utama, 2005. 
International Journal of Advanced Science and Technology Vol.124 (2019) 